DOI: 10.34015/2523-4552.2019.2.12

УДК 343.8

Лазаренко Л. А., кандидат юридичних наук, доцент заступник начальника науково-дослідного центру з питань діяльності органів та установ Державної кримінальновиконавчої служби України і пробації Інституту кримінально-виконавчої служби

\title{
У ПОШУКАХ «ІДЕАЛЬНОЇ» В'ЯЗНИЦІ (ВІД ЗАРОДЖЕННЯ ІДЕЇ ДО ЇЇ РЕАЛІЗАЦІї)
}

У статті з'ясовано зміст концепту «ідеальної» в'язниці в історичному дискурсі та його реалізацію на практиці в межах в'язничних перетворень у зарубіжних країнах упродовж XVIII-XX ст., проаналізовано вплив пенітенціарних ідей I. Бентама на практику виконання покарань та тюремну архітектуру, а також трансформацію концепту нагляду в сучасному світі.

Ключові слова: «ідеальна» в'язниця; I. Бентам; Паноптикум; нагляд; тюремна архітектура.

В статье определено содержание концепта «идеальной» тюрьмы в историческом дискурсе и его реализацию на практике в пределах тюремных преобразований в зарубежных странах в XVIII-XX вв., проанализировано влияние пенитенциарных идей И. Бентама на практику исполнения наказаний и тюремную архитектуру, а также трансформацию концепта надзора в современном мире.

Ключевые слова: «идеальная» тюрьма; И. Бентам; Паноптикум; надзор; тюремная архитектура.

Постановка проблеми. У процесі реформування вітчизняної кримінально-виконавчої системи упродовж останніх років неодноразово було озвучено бажання звести нові сучасні будівлі тюрем і СІ30, умови утримання в яких відповідали б міжнародним вимогам та сучасним стандартам. Але коли доходить до реалізації задуманих проектів, усе, як правило, упирається в нестачу коштів. I справді, «нова» реформована тюремна система - справа витратна. Це доводить увесь світовий досвід: від тюремних реформ, започаткова- них у кінці XVIII ст., і до сьогодення.

Будь-яка реформа в цій сфері у провідних країнах світу розпочиналася 3 проектів нових тюрем. Одним із найбільш вдалих та актуальних донині $\epsilon$ проект Паноптикуму англійського філософа і правника I. Бентама. Пошуки «ідеальної» тюрми, яка б відповідала принципам гуманізму, перевиховувала і виправляла злочинців, започатковані були задовго до І. Бентама, але саме йому вдалося створити проект, що був кардинально новим у плані контро- 
лю та нагляду за засудженими. Актуалізований у 70-80-х роках минулого століття завдяки праці М. Фуко «Наглядати і карати» проект I. Бентама упродовж усього ХX століття реалізовувався на практиці щодо архітектури тюремних будівель та засад організації режиму нагляду.

Нині нового значення набувають технології нагляду та контролю, і стосуються вони не лише правопорушників, що утримуються в спеціальних закладах, а й усіх громадян. Технології моніторингу й ідентифікації людей реалізовуються, як нас запевняють, задля безпеки громадян з метою запобігання можливим правопорушенням (та й самі громадяни дедалі частіше говорять про збільшення кількості камер спостереження в громадських місцях та деінде), але насправді складається враження, що за кожним 3 нас постійно хтось наглядає. Завдяки технологіям людина все більше перетворюється в об'єкт спостереження. I якщо за I. Бентамом лише певні види масової людської діяльності слід контролювати: навчання, відбування покарання у в'язниці, некваліфіковану працю значної кількості робітників на фабриці, то в сучасних умовах технології дозволяють контролювати максимально широке коло суб'єктів, ба навіть і все населення.

Постановка завдання. Мета дослідження - з'ясувати зміст концепту «ідеальної» в'язниці в історичному дискурсі та його реалізацію на практиці в межах в'язничних перетворень упродовж XVIII-XX ст., проаналізувати вплив пенітенціарних ідей I. Бентама на практику виконання покарань і трансформацію концепту нагляду в сучасному світі.
Аналіз останніх досліджень і публікацій. Науково-теоретичною основою дослідження стали праці таких учених, як I. Бентам, М. Фуко, П. Тепляшин, О. Денисов та ін. У процесі аналізу досвіду реалізації теоретичних проектів побудови «ідеальної» в'язниці також використано описи установ виконання покарань, подані в Журналі міністерства юстиції, Тюремному віснику та інших інформаційних ресурсах.

Виклад основного матеріалу. Злочинність зневажає гідність людини, однак нерідко нею нехтує й державна машина. 3 початком гуманізації сфери виконання покарань науковці дедалі частіше наголошують на взаємозв'язку умов утримання, санітарного стану в'язниць і подальшої ресоціалізації. Адже якщо умови будуть пригноблювати гідність людини, то про яке виправлення можна говорити.

у пошуках першого зразка «ідеальної» в'язниці джерела щоразу посилаються на ім'я І. Бентама. Одна 3 його численних праць, а саме «Паноптикон, або Дім інспекції» (1791 р.), присвячена перетворенню тюрем. Саме слово «паноптикон», або «паноптикум», - грецького походження та означає простір, у якому видно все. У цій роботі І. Бентам розглянув новий принцип будівництва й облаштування простору будь-яких споруд, де люди будуть знаходитися під наглядом. Основною була ідея побудови раціональної тюрми, де в камерах засуджені знаходились би відокремлено, а за ними здійснювався централізований нагляд $[1 ; 2]$.

Думки про перебудову тюрми I. Бентам запозичив у свого брата Самуїла, який, перебуваючи на службі у кн. Г. Потьомкіна, подібним чи- 
ном здійснював нагляд за некваліфікованими працівниками мануфактури [3].

У центрі архітектурної споруди, побудованої за зразком паноптикуму, повинна була знаходитися башта, а вздовж периферії - кільцеподібна будівля. У башті повинні бути широкі вікна, звернені до периферійної будови, розділеної на камери або кімнатки, кожна з яких тягнеться на всю ширину будівлі й має два вікна. Одне iз них обернене назовні, через нього в камеру проникає світло, а інше всередину, до вікон башти. Тепер досить у центральну башту помістити наглядача, а в кожну кімнатку засудженого, хворого, божевільного, робітника або школяра, щоб був забезпечений повний нагляд. Наглядач завдяки світлу, що проникає із зовні, може бачити в кожній кімнатцікамері силует людини, що знаходиться там, і стежити, чи поводиться вона як годиться і чи займається визначеною справою [1]. Таким чином, принцип темниці як місця ув'язнення тут було перевернуто тепер нагляд забезпечувало світло і простір. Паноптикум повинен був навіювати людині думку про те, що за нею постійно стежать. Цим, за задумом I. Бентама, і забезпечується перманентність контролю, навіть якщо наглядач втомився й закрив очi.

Концепція паноптикуму лягла в основу більшості як англійських, так і європейських тюремних проектів 30-40 років ХІХ ст. Однією з перших «ідеальних» в'язниць на батьківщині ідеолога паноптикуму в Англії стала в'язниця Пентонвіль. Ї̈̈ будівництво було дозволено двома актами парламенту. Проект розробив капітан Джошуа Вебб з корпусу ко- ролівських інженерів, обізнаний $\mathrm{y}$ справах утримання засуджених в австралійських колоніях. В'язниця призначалася для засуджених до транспортації. Будівництво розпочалося 10 квітня 1840 р. і закінчилося 1842 р. Його вартість склала 84186 фунтів. У в'язниці була центральна будівля, від якої радіально відгалужувалися п'ять крил. Усі крила були видимі для охоронців у центральній будівлі. Ув'язнені утримувалися окремо один від одного в ізоляції. Проте Пентонвіль не являв собою паноптикум. Охоронці не могли бачити, що відбувається в камерах зі своєї центральної позиції. У Пентонвілі могло бути розміщено 520 ув'язнених, кожен з яких перебував у своїй камері 4 м завдовжки, 2 завширшки і 3 - заввишки. У зовнішніх стінах камер були невеликі вікна, двері виходили на вузькі галереї [4, с. 75-78].

Архітектурні новації системи одиночного утримання, спрямованої на унеможливлення спілкування та зменшення рецидиву, дали неочікувані «плоди». Ув'язнені в режимі повного мовчання, одягнені в полотняні маски, для того, щоб не бачити один одного, з вовняними накладками на взутті - для підтримки тиші, часто-густо страждали на душевні розлади. Згідно з офіційними даними, «серед кожних шести тисяч ув'язнених Пентонвіля було 220 випадків безумства, 210 випадків бачення галюцинацій i сорок самогубств» $[4$, с. 78].

Не минуло і 100 років з моменту створення ескізу Паноптикуму, як в Санкт-Петербурзі почали будувати тюрму, в основу якої покладено згаданий принцип. На відміну від старих тюрем-темниць, він передбачав 
максимальну відкритість та освітленість приміщень з метою постійного та всеохопного контролю. Нову сучасну в'язницю було вирішено побудувати на берегах Неви, на місці колишнього Винного містечка. $\mathrm{y}$ 1868 р. його перетворено на в'язницю для короткострокового утримання арештантів. I ось на цьому місці повинна була з'явитися в'язниця, що відповідала основним тогочасним технічним та санітарним нормам.

Проект в'язниці було доручено створити архітектору Головного тюремного управління А. Томішку. Йому невипадково запропонували взятися за цю справу, адже він вже будував тюрми нового зразка в інших містах імперії, а також вивчав тюремне будівництво в Європі. Нова проектована в'язниця за формою являла собою два хрести, а камери планувалися одиночні, на вікнах товсті грати, крізь які проходило повітря та світло.

Будівництво тривало майже 6 років і завершилося 1890 р. Варто зазначити, що при побудові архітектором застосовувалися новаторські ідеї щодо інженерних і технічних питань. Наприклад, саме там було застосовано центральне опалювання. Системи водопостачання, каналізації, електрифікації були автономними. Споруджена за новаторським проектом, ця в'язниця стала взірцевою для Російської імперії кінця XIX початку XX ст. [5].

Паноптикум як зразок приміщення для тюрми був узятий за основу і при побудові 1830 р. «Круглого будинку» (м. Фрімантл, Австралія) місцевим інженером Генрі Уіллі Ревлі. Це була перша капітальна споруда на території колонії Суонрівер. Буді- вля зводилася як в'язниця - 3 8 камерами й кімнатою для наглядача, усі приміщення відкривалися у внутрішній двір. 1982 року «Круглий будинок» перейшов у власність Міської ради Фрімантла і незабаром після цього був відкритий для відвідування. Сьогодні до нього люблять приїжджати весільні кортежі для фотосесій на тлі колоніальної архітектури.

Ідеї I. Бентама чи не найповніше втілено в споруді на острові Хувентуд. Тюрму збудовано під час правління кубинського диктатора Херардо Мачадо всього за 5 років (1926-1931 рр.) за зразком американської в'язниці «Джолієт» (штат Іллінойс). Особливу увагу слід звернути на проект тюрми. П'ять їі корпусів мали вигляд кругової галереї, по 5 поверхів кожна. У теорії її розраховано на 6 тисяч осіб, але за диктаторського правління вона була часто переповнена. У центрі будівлі перебував охоронець, який спостерігав 3 вікон за поведінкою в'язнів зі своєї вежі. Охоронці не контактували 3 ув'язненими й залишали будівлю через підземні тунелі, що зменшувало ймовірність утеч.

Іншими відомими в'язницями, що збудовані за проектом «ідеальної» в'язниці, $€$ Марення Харнем Голландія, Carabanchel Prison - Іспанія, Chi Hoa prison - B'єтнам, Caseros Prison - Аргентина, Huron Historic Gaol - Канада, Millbank Prison - Англія, Mount Eden Prisons - Нова Зеландія, Old Provost - Південна Африка, Palacio de Lecumberri - Мексика, Round House - Австралія, Statesville Correctional Centre - США (Іллінойс).

Те, що надихало I. Бентама, інший відомий філософ і фахівець у питаннях тюрмознавства Мішель 
Фуко пристрасно не сприймав [6] Він ставив під сумнів основу бентамівської утопії - претензію суспільства створювати зручного для себе індивіда. Він назвав Паноптикон механізмом, що дозволяє владі здійснювати абсолютний контроль, не вдаючись до прямого і жорсткого впливу, локалізованого на людському тілі. Мішель Фуко говорив про «карцерний» громадський устрій, про «карцерну мережу», у яку спійманий індивід. Він не приймав сам «тюремний уклад».

Ось враження М. Фуко від відвідування в'язниці: «Здолавши ряд грат та огорожі, думаєш, що потрапив туди, де ув'язненим допомагають знову пристосуватися до життя в суспільстві, до законослухняності. I що ж бачиш замість цього? Місце, де ув'язнені проводять 10-12 годин на добу, є страхітливою кліткою розміром півтора метри на два, з одного боку повністю огородженою. Місце, де ув'язнений знаходиться один, де він спить або читає, де він одягається і справляє нужду, - це клітка для диких звірів. Тут зосереджено усе лицемірство в'язниці» [7]. Мішель Фуко назвав французькі в'язниці інституцією «надзвичайно архаїчною, практично середньовічною, мало не найстарішою і в той же час найжорстокішою у світі».

3 інтерв'ю М. Фуко Дж. Саймону 1974 р.: «В'язниця - це фізичне знищення людей, і тих, хто в ній помирає, буквальне і відразу, і тих, хто $з$ неї виходить, але все таки помирає, хай і не від прямої ії̈ дії, оскільки, вийшовши 3 неї, не знайдеш ні роботи, ні інших джерел існування, сім'ї не заведеш. I, переходячи з однієї в'язниці в іншу, від одного злочину до іншого, ці люди врешті-решт під- даються фізичному знищенню» [7]. Після М. Фуко бентамівські ілюзії вже неможливі.

Однак пошуки «ідеальної» в'язниці не полишені й нині. Проект тюрми за зразком паноптикуму розроблено студенткою Московського архітектурного інституту К. Ішхановою. В'язницю планують побудувати в Свердловській області в середині Саф'янівського мідного кар'єру. В основі проекту - схема пекла в «Божественній комедії» Данте Аліг'єрі. В'язниця має дев'ять поверхів. Лише потрапивши туди, засуджений знаходиться на самому дні ями. У боротьбі за визволення він обмірковує свій вчинок і своєю належною поведінкою виправляється, щоб знову опинитися нагорі споруди, на волі. У проекті передбачено не тільки архітектурне рішення, а й схему маршруту засудженого «вгору». На дні кар'єру знаходиться виправна колонія. В'язнів утримують в окремих камерах. Якщо ув'язнений добре поводиться і виконує всі вимоги режиму, він отримує більше свободи, а також швидше пересувається «колами пекла». Після 75\% строку утримання засудженого переводять до колонії-поселення, яка знаходиться на поверхні рівня. На останньому рівні вони мешкають в самостійно створеному ними середовищі - займаються сільським господарством, спортом [8].

I якщо цей проект є радше просто креативною ідеєю, яка жодним чином не кореспондується із сучасними поглядами на кримінальновиконавчу політику, а повертає нас до темних часів середньовіччя, коли засудженого кидали в яму й забували про нього, то новітні виправні заклади для утримання засуджених, 
зокрема в Данії і Норвегії, справді можуть претендувати на звання «ідеальної» в'язниці XXI ст.

У них враховано сучасні вимоги до процесу відбування покарання, наріжним каменем якого є повага до прав засудженого та його гідності, та новітні технічні можливості нагляду й охорони. Восени 2017 р. в Данії завершено будівництво та введено в експлуатацію найсучаснішу в'язницю країни - Сторстрьом (Storstrøm). Це заклад закритого типу, розрахований на 250 засуджених. На будівництво в'язниці витрачено 1 млрд. дан. крон (приблизно 154 млн. доларів США), що $\epsilon$ рекордною сумою для Данії (для порівняння: норвезька в'язниця Халден коштувала 256 млн доларів). 300 камер відеоспостереження та найсучасніші електронні засоби охорони роблять її найбезпечнішою установою виконання покарання в країні. На території в'язниці - 10 будівель (по 5 - для ув'язнених і для загальних потреб та адміністрації). У в'язниці Сторстрьом створено підгрунтя для найбільш гуманного відбування покарання засудженими та умови для їх найефективнішої ресоціалізації. Особливу увагу звернуто на естетику та якість будівель, адже, на думку фахівців, приємна обстановка сприяє створенню позитивного настрою, фізичному та психічному благополуччю як засуджених, так і персоналу.

Після відвідин нової тюрми журналістами цілком справедливо постало питання, чи доречно для засуджених створювати такі «розкішні» умови утримання: камери 3 ванними кімнатами, у кожній телевізор, холодильник, у спортивних залах - сучасне обладнання тощо. На це представник Директорату тюрем i пробації Данії відповів: «ми зводили заклад відповідно до сучасних умов існування цивілізованої людини, наявність туалету в камері $є$ не лише атрибутом комфорту, а й безпеки персоналу та економії ресурсів - засудженого в такому разі не треба супроводжувати до загального туалету». Коли 1862 р. відкрили пенітенціарій Врідсльозелілле $з$ центральним опаленням, електричним світлом та водопроводом, у громадськості виникали такі самі питання. Фактично, як зазначає представник Директорату, у Данії намагалися звести тюрму майбутнього, яка б не потребувала модернізації найближчі 100 років [9].

Однією з найновітніших і найгуманніших в'язниць також вважається тюрма на о. Бастой у Норвегії. Вона і справді втілює мрії ув'язнених усього світу. Начальник цієї установи зазначає, що до засуджених треба ставитися, як до людей; якщо ж цього не робити, то вони вийдуть на свободу злими тваринами i знову повернуться на злочинний шлях. I схоже, ця методика справді діє, адже згідно зі статистикою лише 16\% колишніх ув'язнених о. Бастой учиняють злочини після відбування попереднього покарання. Засуджені мешкають в окремих будиночках по шість осіб у кожному. У кожного засудженого $є$ своя кімната. При цьому вони не обмежені в пересуванні територією острова. Ця в'язниця може нагадати звичайне норвезьке поселення. Удень його мешканці працюють, а ввечері - ловлять рибу чи купаються. Площа острова становить трохи більше двох квадратних кілометрів. Тут мешкають усього 115 людей, серед них - 35 охоронців. Вони рахують засуджених чотири рази 
на добу - зранку, удень, увечері та перед відбоєм. Після 16-ї години на острові залишаються лише 4 охоронці [10].

Висновки. Як бачимо, у сучасних умовах паноптична модель в'язниці не втратила актуальності, але нагляд забезпечується вже не архітектурними засобами, а технічними. Крім того, контроль і нагляд $€$ лише однією, але не основною, складовою багатокластерної системи відбування покарання.

Історичним же будівлям тюрем, спорудженим за колись такою популярною моделлю I. Бентама, дедалі частіше відводиться роль артоб'єктів. На щастя, є організації та групи, які дають нове життя покинутим будівлям. Таким прикладом $\epsilon$
Архітектурна студія Rojkind Arquitectos (Мехіко), яка представила свій конкурсний проект Національного історико-архівного музею, експозиції якого розмістяться в Palacio de Lecumberry (палац Лекумберрі) колишній будівлі головної в'язниці мексиканської столиці. Було вирішено зберегти незмінним фасад центральної вежі, що раніше використовувалася переважно тюремною охороною. Застигла в камені частка минулого допоможе гостям Palacio de Lecumberri краще зрозуміти історію мексиканського суспільства [11]. Досвід збереження національної пам'яті через шанобливе ставлення до таких специфічних історичних об’єктів варто було б запозичити i нам.

\section{Список використаних джерел}

1. Bentham J. Panopticon; or, The inspection house. Dublin, 1791. $240 \mathrm{~s}$.

2. Бентам и его время / Покровский П., прив.-доц. Петрогр. ун-та. Петроград : Тип. А. Э. Коллинс, 1916. 704 с.

3. What does the panopticon mean in the age of digital surveillance? The Guardian URL: $\quad$ https://www.theguardian.com/technology/2015/jul/23/panopticon-digitalsurveillance-jeremy-bentham (дата звернення: 11.04.2019).

4. Тепляшин П. В. Истоки и развитие английского тюрьмоведения: монография. Красноярск : Сибирский юридический институт МВД России, 2005. 253 с.

5. Перов Л. В. Классик тюремного зодчества. История Петербурга. 2004. №6 (22). C. 55-60.

6. Фуко М. Наглядати й карати: Народження в'язниці ; пер. $з$ фр. П. Таращук. Київ : Основи, 1998. 392 с.

7. Дьяков А. В. Мишель Фуко: о «смерти человека», о свободе и о «конце философии». Вестник истории и философии КГУ. Серия «Философия». 2008. № 2. С. 4553.

8. В России предложили построить тюрьму по проекту ада Данте. URL : http: //pravo.ru/news/view/75362/(дата звернення: 11.04.2019).

9. Сокальська О.В. Державні в'язниці відкритого та закритого типу в пенітенціарній системі Данії. Альманах права. Правова аналітика: доктринальні nідходи та галузеві виміри. Випуск 9. Київ : Ін-т держави і права ім. В. М. Корецького НАН України, 2018. С. 481-486.

10. Динкевич М. Идеальная тюрьма: мечта заключенных всего мира URL: http://www.vesti.ru/doc.html?id=1041060 (дата звернення: 11.04.2019).

11. ART UKRAINE : Головна в'язниця Мехіко перетвориться на Національний історико-архівний музей. URL: http://artukraine.com.ua/ukr/n/glavnaya-tyurma- 
mehiko-prevratitsya-v-nacionalnyy-istoriko-arhivnyy-muzey-foto/\#.VSIlI_msUjU

(дата звернення: 11.04.2019).

\section{References}

1. Bentham, J. (1791). Panopticon; or, The inspection house. Dublin [in English]. Russian].

2. Pokrovskij, P. (1916). Bentam i ego vremya. Petrograd : Tip. A. E. Kollinss [in

3. What does the panopticon mean in the age of digital surveillance? The Guardian URL: $\quad$ https://www.theguardian.com/technology/2015/jul/23/panopticon-digitalsurveillance-jeremy-bentham (accessed: 11.04.2019) [in English].

4. Teplyashin, P. V. (2005). Istoki i razvitie anglijskogo tyurmovedeniya: monografiya. Krasnoyarsk: Sibirskij yuridicheskij institut MVD Rossii [in Russian].

5. Perov, L. V. (2004). Klassik tyuremnogo zodchestva. Istoriya Peterburga, 6 (22), 55-60 [in Russian].

6. Fuko, M. (1998). Naglyadati j karati: Narodzhennya v'yaznici ; per. z fr. P. Tarashuk. Kiyiv : Osnovi [in Ukrainian].

7. Dyakov, A. V. (2008). Mishel Fuko: o «smerti cheloveka», o svobode i o «konce filosofii». Vestnik istorii i filosofii KGU. Seriya «Filosofiya», 2, 45-53 [in Russian].

8. V Rossii predlozhili postroit tyurmu po proektu ada Dante. URL : http: //pravo.ru/ news/view/75362/(accessed: 11.04.2019) [in Russian].

9. Sokalska, 0. V. (2018). Derzhavni v'yaznici vidkritogo ta zakritogo tipu v penitenciarnij sistemi Daniyi. Almanah prava. Pravova analitika: doktrinalni pidhodi ta galuzevi vimiri, 9, 481-486 [in Ukrainian].

10. Dinkevich, M. Idealnaya tyurma: mechta zaklyuchennyh vsego mira URL: http://www.vesti.ru/doc.html?id=1041060 (accessed: 11.04.2019) [in Russian].

11. ART UKRAINE : Golovna v'yaznicya Mehiko peretvoritsya na Nacionalnij istoriko-arhivnij muzej. URL: http://artukraine.com.ua/ukr/n/glavnaya-tyurma-mehikoprevratitsya-v-nacionalnyy-istoriko-arhivnyy-muzey-foto/\#.VSIlI_msUjU (accessed: 11.04.2019) [in Ukrainian].

L. Lazarenko, PhD in Law, Associate Professor, Deputy Head of the ScientificResearch Centre on Activities of the Bodies and Establishments of the State CriminalExecutive Service of Ukraine and Probation of Institute of Criminal-Executive Service

\section{Looking for the «ideal» prison (from the idea to its implementation)}

The article clarifies the content of the concept «ideal» prison in historical discourse and its implementation in practice in the framework of the prison transformations in some countries during XVIII - XX centuries. The influence of I. Bentham's penitentiary ideas on the practice of punishment and imprisonment is analyzed. architecture and transformation of the concept of supervision in the modern world.

The founder of the idea of the «ideal» prison is the English philosopher and lawyer I. Bentham. In his work «Panopticon; or, The Inspection House» (1791) I. Bentham gave the new principle for the construction and arrangement of the buildings and premises, in which people are under supervised. The main idea was to construct the rational prison, where the convicts would be isolated in cells, and then centralized supervision would be carried out. The panopticon concept was the 
basis of most of the British and European prison projects of XIX - middle of $\mathrm{XX}$ centuries.

In modern conditions the panopticon model of prisons has not lost its relevance, but supervision is already provided not by the architectural means, but by the technical ones. In addition, control and supervision are not the main component of the multi-cluster system of serving sentences. The latest prisons, in particular in Denmark and Norway, can be qualified as the «ideal» ones in the XXI century. They take into account modern requirements to the process of serving sentences. The cornerstone is the respect to the rights of the convicted persons and their human dignity, as well as the latest technical means of supervision and control.

Keywords: «ideal» prison; I. Bentham; Panopticon; supervision; prison architecture.

Надійшла до редакції 21.06.2019 